\title{
Do Stereotypic Behaviors in Autism Warrant Intervention?
}

\author{
Christopher W Tarr* \\ Slippery Rock University of Pennsylvania, USA
}

Submission: September 11, 2020; Published: September 14, 2020

*Corresponding author: Christopher W Tarr, Slippery Rock University of Pennsylvania, USA

\section{Abstract}

This opinion answers the question "Do Stereotypic Behaviors in Autism Warrant Intervention?" This author recently had an article published that examined the effects of a particular intervention on stereotypic behaviors in individuals with autism. Immediately after publication, this author was asked if stereotypic behaviors were detrimental enough to warrant intervention. Based on my published research and the research of others, my response is an emphatic "yes." This opinion outlines the detrimental effects of stereotypic behaviors in individuals with autism. This opinion explores the research past and present. Finally, this opinion discusses areas in which more research is needed.

Keywords: Autism; Behaviors; Research; Behaviors; Educational; Social development

\section{Introduction}

I recently had an article published that examined the effects of a particular intervention on stereotypic behaviors in individuals with autism. Immediately after publication, I was asked if stereotypic behaviors were detrimental enough to warrant intervention. My opinion is yes and that the scientific field is lacking sufficient research on these behaviors. Stereotypic behaviors are the most likely of all problem behaviors to require intervention and stereotypic behaviors are major barriers to proper educational and social development [1]. In addition, Lee et al, [2] reported that problem behaviors, such as stereotypic behaviors, have the potential to create social stigma and reduce the number of opportunities for full societal integration. Yet, when researching stereotypic behaviors, words such as "sparse", "limited", and "poorly defined" are used to describe the available information.

\section{Synopsis of Research:}

Stereotypic movements have been viewed as a hallmark characteristic of autism spectrum disorder since 1943 when Leo Kanner, a child psychiatrist, first described early infantile autism. We know that some individuals with autism spend a vast amount of time engaged in stereotypic behaviors. These behaviors can occur frequently, intensely, and appear bizarre. These behaviors can range from hand flapping to toe walking. These behaviors can be motoric, vocal, or visual in nature. Stereotypic behaviors can be disruptive and harmful.
For some individuals with autism, stereotypic behaviors, have a very negative effect on their ability to function and learn. The detrimental effects of stereotypic behaviors were first observed by Risley [3], when attempting to determine the effects and side effects of punishment of autistic behaviors, it was observed that as stereotypic behaviors decreased appropriate behaviors increased. Risley [3] termed this relationship "functional incompatibility." Subsequent research suggest that stereotypical behaviors interfere with a person's ability to learn new information and recite previously learned information [4-6], result in increased response latencies [7], interfere with a child's ability to engage in appropriate play behaviors [8] and are socially stigmatizing [9]. More recent research has replicated the negative effects stereotypic behaviors. Research has demonstrated that stereotypic behaviors pose barriers to the ability to learn by observing others [10]. Powell et al, [11] showed that these behaviors can prevent the ability to develop play skills. Sigafoos et al. [12] demonstrated that stereotypic behaviors decrease participation in academic tasks.

More alarming, stereotypic behaviors have been identified as a reliable precursor for self-injurious behaviors [13]. Oliver et al, [13] studied 943 children who attended schools for children with intellectual disabilities. The study revealed that the presence of high-frequency stereotypic behaviors was significantly associated with the presence and severity self-injurious, aggressive, and 
destructive behaviors when controlling for potential confounding variables. Oliver et al, [13] suggested that the presence of stereotypic behaviors should be investigated as a potential risk marker for future development of self-injurious, aggressive, and destructive behaviors.

Bodfish et al, [14] stated that compared to the other core characteristics of autism, stereotypic behaviors receive far less attention. There is much more to learn about stereotypic behaviors. There is still much debate on the causes of stereotypic behaviors, how to accurately define, assess, quantify, and how to assign interventions to these behaviors. Therefore, a better understanding of these behaviors is warranted.

More research is warranted on the differing functions of stereotypic behaviors. Early hypotheses on the possible functions of stereotypic behaviors were for automatic reinforcement, to provide sensory input, and to cope with anxiety. Current research has demonstrated that stereotypic can serve different functions. Research supports the idea that stereotypic behaviors have multiple functions and these behaviors have been shown to enter into contingencies of social and negative reinforcement [15]. Some suggest that stereotypic behaviors should be defined by function and not by topography or presentation.

More research is needed to determine the causes of stereotypic behaviors. Research has demonstrated that many structures and processes of the brain could be the cause of stereotypic behaviors. Structures such as the basal ganglia, cerebellum, and hippocampus could contribute to the cause of stereotypic behaviors. In addition, the dopamine, serotonin, and GABA neurotransmitters have been identified as possible causes to the production of stereotypic behaviors. However, no single explanation of neurobiological process dysfunction exists to explain the expression of stereotypic behaviors [16]. In my experience from working in the field of autism, clinicians prioritize skill building over reducing stereotypic behaviors. The research demonstrates that only when stereotypic behaviors are decreased, we experience a learning of socially appropriate skills. Therefore, it is my belief that decreasing stereotypic behaviors is warranted. I propose that researchers and behavior analysts adopt an Always Understand The Inner Stereotypic Message mindset. We must reduce stereotypic behaviors before attempting to teach new skills.

\section{Conclusion}

A high percentage of individuals with autism engage in stereotypic behaviors. These behaviors consume a large amount of a person's time, serve many different functions, and have detrimental effects. Yet, these behaviors appear to receive less attention than the social communication and social deficit symptoms of autism. I agree with Koegel and Covert (1972) who reported that if we desire to teach individuals with autism new skills, we must first suppress stereotypic behaviors. Yes, stereotypic behaviors are detrimental enough to warrant intervention and yes, these behaviors require more research. When prioritizing interventions, researchers should seek to decrease stereotypic behaviors before attempting to increase communication and/ or social skills. This author proposes an Always Understand the Inner Stereotypic Message mindset.

\section{References}

1. Horner R H, Carr E G, Strain P S, Todd A W, Reed H K (2002) Problem behavior interventions for young children with autism: A research synthesis. Journal of Autism and Developmental Disorders 32(5): 423-446.

2. Lee S, Odom S L, Loftin R (2007) Social engagement with peers and stereotypic behavior of children with autism. Journal of Positive Behavior Interventions 9(2): 67-79.

3. Risley T R (1968) The effects and side effects of punishing the autistic behaviors of a deviant child. Journal of Applied Behavior Analysis 1: 21-34.

4. Koegel R L, Covert A (1972) The relationship of self-stimulation to learning in autistic children. Journal of Applied Behavior Analysis 5(4): 381-387.

5. Runco M A, Charlop M H, Schreibman L (1986) The occurrence of autistic children's self-stimulation as a function of familiar versus unfamiliar stimulus conditions. Journal of Autism and Developmental Disorder 16(1): 31-44.

6. Morrison K, Rosales-Ruiz J (1997) The effect of object preferences on task performance and stereotypy in a child with autism. Research in Developmental Disabilities 18(2): 127-137.

7. Lovaas I, Litrownik A, Mann R (1971) Response latencies to auditory stimuli in autistic children engaged in self-stimulatory behavior Behavior Research and Therapy 9: 39-49.

8. Koegel R L, Firestone P B, Kramme K W, Dunlap G (1974) Increasing spontaneous play by suppressing self-stimulation in autistic children. Journal of Applied Behavior Analysis 7(4): 521-528.

9. Jones R S P, Wint D, Ellis N C (1990) The social effects of stereotyped behavior. Journal of Intellectual Disability Research 34(3): 261-268.

10. Matson J L, Nebel-Schwalm M (2007) Assessing challenging behaviors in children with autism spectrum disorders: A review. Research in Developmental Disabilities 28(6): 567-579.

11. Powell D, Dunlap G, Fox L (2006) Prevention and intervention for the challenging behaviors of toddlers and preschoolers. Infants and Young School Children 19: 25-35.

12. Sigafoos J, Arthur M, O'Reilly MF (2003) Challenging behavior and developmental disability. Whurr Publishers.

13. Oliver C, Petty J, Ruddick L, Bacaraese-Hamilton M (2012) The association between repetitive, self-injurious and aggressive behavior in children with severe intellectual disability. Journal of Autism and Developmental Disorders 42: 910-919.

14. Bodfish JW, Symons F J, Parker D E, Lewis M H (2000) Varieties of repetitive behavior in autism: Comparisons to mental retardation. Journal of Applied Behavior Analysis 30(3): 237-243.

15. Cunningham A B, Schreibman L (2008) Stereotypy in autism: The importance of function. Research in Autism Spectrum Disorder 2(3): 469-479.

16. Rapp J T, Vollmer T R (2005) Stereotypy I: A review of behavioral assessment and treatment. Research in Developmental Disabilities 26(6): 527-547. 

(C) This work is licensed under Creative BY DOI: 10.19080/GJIDD.2020.07.555701
Your next submission with Juniper Publishers will reach you the below assets

- Quality Editorial service

- Swift Peer Review

- Reprints availability

- E-prints Service

- Manuscript Podcast for convenient understanding

- Global attainment for your research

- Manuscript accessibility in different formats ( Pdf, E-pub, Full Text, Audio)

- Unceasing customer service

Track the below URL for one-step submission https://juniperpublishers.com/online-submission.php 